\title{
Sinophobia in the Post-Soviet Space
}

\section{A Reaction to Expansion or A Challenge to Integration?}

Yuri V. Kulintsev, Alibek A. Mukambaev,
Kubatbek K. Rakhimov, Ivan Yu. Zuenko

\author{
Yuri V. Kulintsev, MBA in Management in Asia \\ North-East Asia Strategic Issues and SCO Center, Institute of Far Eastern Studies \\ Russian Academy of Sciences, Moscow, Russia \\ Research Fellow \\ ORCID: 0000-0002-4906-6866 \\ Researcher ID: AAK-4804-2020 \\ Scopus Author ID: 57214315908 \\ E-mail: kulintsev.y@ifes-ras.ru \\ Address: 32 Nakhimovsky Ave., Moscow 117997, Russia \\ Alibek A. Mukambaev \\ "Agency for Strategic Initiatives - Eurasia" Public Foundation, Kyrgyz Republic \\ President \\ ORCID: 0000-0003-4809-2541 \\ E-mail: alibek.mukambaev@gmail.com \\ Address: 24a-4 Aitmatova Ave., Bishkek 720003, Kyrgyz Republic \\ Kubatbek K. Rakhimov, PhD in Economics \\ Advisor to the Prime-Minister of the Kyrgyz Republic; \\ "Agency for Strategic Initiatives - Eurasia" Public Foundation \\ Chairman of Expert Council \\ ORCID: 0000-0003-3756-9375 \\ E-mail: kubat.rakhimov@gmail.com \\ Address: 207 Abdymomunova Str., Bishkek 720003, Kyrgyz Republic
}




\title{
Ivan Yu. Zuenko
}

Department for Chinese Studies, Institute of History, Archaeology and Ethnology, Russian Academy of Sciences, Far Eastern Branch, Vladivostok, Russia

Research Fellow

ORCID: 0000-0002-9853-9703

Researcher ID: AAB-5070-2020

Scopus Author ID: 57211944845

E-mail: zuenko@ihaefe.ru

Address: 89 Pushkinskaya Str., Vladivostok 690001, Russia

DOI: $10.31278 / 1810-6374-2020-18-3-128-151$

\begin{abstract}
A team of authors representing various countries of the Eurasian Economic Union analyzed anti-Chinese protests that took place in the 2010s in Russia, Kazakhstan, and Kyrgyzstan-EAEU countries that are China's partners in implementing the Belt and Road Initiative. Based on empirical data concerning anti-Chinese protests, the paper examines the reaction of the authorities, public and expert discussion on the causes and further development of the situation, and offers some recommendations to the authorities of the countries in question on how to build constructive cooperation with China.

An analysis of the causes and mechanisms of anti-Chinese protests in various countries shows that, despite some specific features, these countries face similar problems. The current situation can only partly be explained by the natural reaction of society to the continuing economic expansion of China. The basic reason for the protests was the lack of public trust in statements made by the authorities and the failure of existing governmentsociety feedback mechanisms. As a result, society did not understand and rejected certain cooperation projects with China even though they were beneficial for the socioeconomic development of the countries and regions being considered.
\end{abstract}

Keywords: China, Sinophobia, anti-Chinese protests, integration, Belt and Road, EAEU. 
nti-Chinese protests that took place in 2019 in Kazakhstan,
Russia, and Kyrgyzstan show that Sinophobic sentiment
remains strong in countries that border China. But such feelings are common not only among China's neighbors; they rose globally even before the coronavirus pandemic (Zhang, 2008).

Sinophobia itself (as well as the so-called "yellow threat" in general) is not a new phenomenon. It is clearly recorded in 19th century sources and literature (see, for example, Dyatlov, 2000). More surprising is how it coexists with integration discourse and a positive foreign policy agenda towards China among most of its partners (Gabuev, 2018). It is equally interesting that Sinophobia has not disappeared following China's intensified and focused efforts undertaken in recent decades to improve its image-what Joseph Nye defines as 'soft power' (Nye, 2004).

However, the question can be put differently: Could Sinophobia and anti-Chinese sentiment be a natural reaction of society to Beijing's increasingly tough foreign policy rhetoric (the so-called "wolf-warrior diplomacy," see Denisov, 2020), and China's economic, demographic, and cultural expansion, which, in turn, can be considered through the lens of Beijing's neocolonialist policy?

This article, co-authored by experts from Russia and Central Asia, seeks to analyze Sinophobic discourse specifically in the post-Soviet space. While recognizing the fact that alarmist feelings in this region are part of the global trend, the authors still consider it possible to concentrate on specific examples of anti-Chinese protests that took place in Russia, Kazakhstan, and Kyrgyzstan. These three territories were selected for good reason: together, these sates, which are also members of the Eurasian Economic Union (EAEU), share 94 percent of China's border with post-Soviet countries, which makes them its key partners in the implementation of the Silk Road Economic Belt initiative and other integration projects. Understanding the reasons for anti-Chinese sentiment and a possible course of events is the key to constructive development of relations between these countries and China.

Taking into account the relevance and practical significance of this topic, the authors decided to focus on four tasks: 1) an overview 
of Sinophobic manifestations; 2) an analysis of the reaction of the authorities; 3 ) a study of public and expert discussion regarding the factors contributing to anti-Chinese sentiments and further development of the situation; 4) recommendations to the authorities of the countries under consideration on how to build constructive cooperation.

This approach predetermined the structure of the work, which consists of three parts, in each of which the first three tasks are addressed successively for the three countries: Kazakhstan, Kyrgyzstan, and Russia (particularly its Far Eastern and Baikal regions). Forecasts and recommendations are made in the final part of the work. The sequence of countries reflects the degree to which anti-Chinese sentiments are critical for the state: in Kazakhstan, protests represented the strongest challenge for new President Kassym-Jomart Tokayev and swept across the entire country, while in Kyrgyzstan and Russia they occurred in individual localities.

\section{MANIFESTATIONS OF SINOPHOBIA IN KAZAKHSTAN}

Anti-Chinese protests in Kazakhstan in 2019 were not the first mass manifestation of Sinophobia, which has been widespread in that country since the Soviet period and dates back to pre-revolutionary times.

Sociological polls reveal a consistently high level of Sinophobia in Kazakhstan, which is higher in regions located far away from China, where, for objective reasons (geographical location, peculiarities of the production base), representatives of small and mediumsized businesses lack close economic ties with China, and ordinary citizens have very limited experience of practical interaction with the neighboring country (Mashaev, 2019).

In Western Kazakhstan, a significant part of the local population, including Oralmans (ethnic Kazakhs who have moved in from abroad), works in joint ventures related to the oil industry. Chinese managers often hold leading positions in these companies, thus forming in the minds of local residents the image of a successful foreigner who profits from Kazakhstan's natural resources. Added to this is the dissatisfaction of people with their own social situation or the lack of jobs in the 
attractive oil sector. This creates a set of factors that cause social tensions in the region (Kulintsev, 2019) which can easily be redirected against Chinese.

Chinese diplomats, who act rather arrogantly with regard to Kazakhstan, also add fuel to the fire. In 2013, the director of the Department of European-Central Asian Affairs in the Chinese Ministry of Foreign Affairs, Zhang Hanhui, insulted M.M. Auezov, the former first ambassador of Kazakhstan to China and the son of a famous Kazakh writer, who had made some alarmist statements (Burdin, 2013). In 2016, China unilaterally tightened tourist and business visa requirements for Kazakhstani citizens, but when Astana reciprocated, Zhang Hanhui, by that time appointed ambassador of China, exploded: "The regulations are too tough, humiliating! Do they [Kazakhs] have any idea who they are dealing with?” (Mikhailov, 2016).

In the same year 2016, mass rallies were held in the country to protest against amendments to the Land Code, which allowed the sale and lease of agricultural land to foreigners (Fergana, 2016). People feared that a significant share of land would get under the control of foreigners, including Chinese citizens. Eventually the amendments were put on hold, marking a significant victory of anti-Chinese protesters.

Subsequently, China's actions provided several more reasons for the rise of Sinophobic sentiment. In 2017-2018, the Kazakhstani public was concerned about the situation of ethnic Kazakhs in China's Xinjiang Uyghur Autonomous Region (XUAR) (Zuenko, 2018). In April 2020, an anonymous Chinese blogger posted an article with a provocative title, "Why Is Kazakhstan Seeking to Return to China," on the commercial online service sohu.com. Although this was probably a private initiative and it had nothing to do with the Chinese government, the very fact of its publication, exposed by an activist of the XUAR returnee movement, Serikzhan Bilash, caused a scandal, with the Foreign Ministry of Kazakhstan eventually declaring an official protest (Denisov, 2020).

The negative information background catalyzed the growth of anti-Chinese sentiment in Kazakhstan in 2016-2020. The strongest anti-Chinese protests took place in the early fall of 2019, ahead of 
new Kazakhstani President Tokaev's first state visit to China. It all started in the city of Zhanaozen in the Mangystau Region (west of the country), where several dozen residents opposed the construction of joint ventures with China in the oil and gas sector and urged the government to seek investments in the West, not loans in China (Umarov, 2019). Protests continued for several weeks. Rallies under the "We are against Chinese expansion" and "No to Chinese factories" slogans were held in several large Kazakhstani cities as well, including Aktobe, Shymkent, Almaty, Uralsk, Aktau, and the country's capital. In addition, the protesters demanded that President Tokaev cancel his official trip to Beijing scheduled for September. Mukhtar Ablyazov, the leader of the opposition movement Democratic Choice of Kazakhstan (banned in Kazakhstan), who is currently living in France, assumed responsibility for the protests.

The Kazakhstani authorities could not ignore these antiChinese protests. The head of the city administration met with the demonstrators to explain the situation, which was basically the first case of such direct dialogue between government officials and people. However, the authorities still had to use force. According to official reports, about 50 people were detained in the capital city, four of whom faced administrative charges and the rest were released after a conversation with police; about 30 people were detained in Almaty and some 20 people in Shymkent (RIA Novosti, 2019). Most of them were apprehended for participating in an unauthorized rally.

A few days after the start of the protests, the Kazakhstani authorities organized a press conference, where Deputy Prime Minister Zhenis Kassymbek explained to the public that Chinese projects were being implemented under an intergovernmental agreement, that they were necessary for the national economy and did not carry the threats the protesters were talking about (Sevostyanova, 2019). He responded to practically every statement made by the protesters, giving substantiated answers supported by facts and figures. The demands that President Tokaev cancel his visit to China and stop bilateral economic cooperation with it were left unanswered because they were obviously unrealistic. 
The Foreign Ministry stressed that Kazakhstan considered China a provider of technologies and investments, and that Kazakh-Chinese projects implied the invitation of foreign specialists only at the stages of construction and initial operation (Kovaleva, 2019). In October 2019, one of the leading news agencies in Kazakhstan, Khabar, released a 20-minute documentary film titled "Close Neighbor. Reality without Myths," in which leading political scientists and Chinese scholars and economists made an expert assessment of the current level of relations between Kazakhstan and China, and also explained the reasons for Sinophobia in Kazakhstan (Khabar, 2019). The film clearly showed that bilateral trade and economic cooperation between the two countries was on the rise and Kazakhstan's debt to China was decreasing.

The government of Kazakhstan was able to stabilize the discontent that started in September 2019, thus preventing it from getting out of control. However, this is one of those cases when the symptoms are relieved, but the causes of the disease are not eliminated.

The public outrage was caused by four main factors that are behind the negative attitude towards the " 55 Chinese projects" which triggered public discontent.

Firstly, Kazakhstanis fear that China will supply obsolete equipment, unclaimed on the international market, to their country. Secondly, current experience shows that joint ventures created with China employ mainly Chinese citizens who come along with investments. As a result, local residents get no new jobs at all or their employment is very limited. Thirdly, they worry that Chinese projects will transfer harmful industries from China to neighboring countries, which will have a negative impact on the environmental situation in Kazakhstan. And finally, people think that due to the corruption of Kazakh officials, projects will not be completed on time, and significant funds will be wasted.

Based on this, it can be stated that the authorities are unable to convey their position to people due to the absence of effective feedback mechanisms. The lack of reliable and detailed information about specific cooperation projects with China, coupled with unresolved social problems and real government corruption caused growing 
frustration in regions, exacerbated by a wary attitude towards China due to the persecution of ethnic Kazakhs in XUAR and impetuous actions of Chinese diplomats and social media.

Sinophobia in the western regions of the country provided a reason for expressing distrust of the state and became an internal political factor which external actors hurried to use. Some experts believe that the protests in Kazakhstan were inspired by Western countries interested in undermining China's cooperation with neighboring states (Kulintsev, 2019). Western media portray China as the main demographic threat and a factor that deprives Kazakhstanis of jobs (News-Front, 2019). In addition, some argue that the protests were organized by political groups inside Kazakhstan which are displeased with new President Tokaev who obviously does not want to be a passive player, but seeks to become a full-fledged leader of the state (Klevtsova, 2019).

\section{MANIFESTATIONS OF SINOPHOBIA IN KYRGYZSTAN}

Anti-Chinese protests in Kyrgyzstan started in 2016, when a terrorist act was staged near the Chinese Embassy in Bishkek, and were caused by several factors.

Firstly, it is dissatisfaction with the activities of mining, especially gold mining, companies with Chinese capital. Secondly, it is fears of a possible transfer of land to Chinese companies. Thirdly (this factor is specific just for Kyrgyzstan) it is concerns about the growing debt to China, which at the end of 2019 stood at $\$ 1.7$ billion (approximately $50 \%$ of the total external debt). In fact, the debt increased with frightening speed from $\$ 9$ million in 2008 to $\$ 1.7$ billion in 2019 (Sputnik, 2019). A number of media outlets, including Radio Azattyk (a project of the American Radio Liberty), actively spurred these concerns, citing Tajikistan which was forced to cede 1,100 square kilometers of disputed territories to China, allegedly as debt repayment (Glushkova, 2011).

Although the debt was growing rapidly, the Kyrgyz authorities remained optimistic. Former President Almazbek Atambayev repeatedly said that "there is no need to be afraid of taking loans" (Akchabar, 2016). He explained his position by the fact that loans were 
taken for infrastructure and energy projects: the construction of power lines and roads, and the modernization of the Bishkek thermal power plant. However, the terms on which the loans were taken and the way they were used sparked conflicts within the elite and caused discontent in society. This created a negative image of China in Kyrgyzstan. China was blamed for the "creeping seizure of the economy" through loans issued against state guarantees and for conniving at government corruption. Facts prove that popular discontent was not unfounded. For example, two former prime ministers, several high-ranking officials from the energy sector and a former mayor of Bishkek have been convicted for the misuse of Chinese loans earmarked for the reconstruction of the Bishkek thermal power plant. Former President Atambayev, although he is in a detention center for a different reason, has also been accused of financial fraud involving Chinese loans. It should not be forgotten that anti-corruption measures were adopted as a means of political struggle between elites, causing, among other things, deep public distrust of Chinese investments as such.

For example, the operation of Chinese mining companies, primarily gold-mining ones, meets a strong negative reaction from the local population (Hughes, 2012). Although the protests are directed against investors and the owners of companies, regardless of their nationality, Chinese citizens hold a significant part of exploration and development licenses, and this creates the impression that the protests are aimed at China.

A typical example is the situation concerning the Solton-Sary gold deposit in the Naryn Region. In 2011, the Chinese company Zhong Ji Mining acquired a license to develop one of the sites. The first antiChinese action began shortly thereafter. Protests took place again in the summer of 2019. Local residents claimed that the Chinese company had polluted water and soil, causing the death of their livestock (Kloop, 2019). However, veterinarians concluded that the animals had died because they had not been vaccinated in due time. But for preventive purposes and in order to ease the tensions, the Chinese company was ordered to pay compensation to the livestock farmers, which they took as indirect proof of their claims. 
In addition, in August 2019, a conflict occurred between the Chinese workers of Zhong Ji Mining and local residents, after which two Kyrgyz citizens were taken to hospital with various injuries. Later a rally was held in front of the company's office in Naryn, where several hundred local residents demanded that the enterprise be closed and all Chinese workers leave the country. The protesters did not listen either to the plenipotentiary representative of the government, or the interior minister, or a deputy prime minister who had been sent there for talks with them (Conflict, 2019). As a result, the owners of the company took the bulk of the equipment and Chinese workers out of the city. As of March 2020, the government commission had not yet made any decision as to whether the company could continue operation at the deposit or not. The future of the enterprise is also unclear.

It is noteworthy that a number of media outlets, including Radio Azattyk (Nurmatov, 2019), the Kyrgyz BBC service (Ryskulova, 2019), and the Kloop.kg news site (Kloop, 2019), emphasized environmental problems when covering this topic, although the true causes of the conflict are obviously different. Local residents mined gold, illegally washing it in nearby streams and rivers, as well as at the deposit itself. For many of them this was the main source of income. Intensive industrial development of the field put their business at risk (Kloop, 2019). On the one hand, people lost their illegal earnings, on the other hand, they did not get full-time and well-paid jobs from the Chinese company, which ignored Bishkek's recommendations and continued to use workers from China.

In early 2020, new anti-Chinese protests took place. This time they were caused by plans to build the industrial trade and logistics center At-Bashi in the Naryn Region, 100 kilometers from the border city of Torugart. Earlier it had been announced that China would invest \$280 million in the project which would eventually create 15,000 new jobs for local residents, although no more than 70,000 people lived in the district. The Directorate of the Naryn free economic zone is to allot 170 hectares of land for 49 years for the construction of a complex of warehouses, terminals, hotels, catering enterprises and a gas station (Usenbaeva, 2020). 
Despite the positive rhetoric regarding the project, rallies and protests were held in At-Bashi in January and February 2020, during which people voiced their fears that "the land has already been sold to the Chinese." In order to avoid a conflict, in mid-February the Chinese investor decided to terminate the project and sent a letter to the government of Kyrgyzstan demanding the return of about $\$ 600,000$ paid earlier (Jumasheva, 2020). As in the case of the Solton-Sary mine deposit, the interests of local businessmen and politicians who actively use anti-Chinese rhetoric in the media and social networks to solve their own problems can be considered the likely cause of anti-Chinese protests.

However, it must be admitted that China's persistence in promoting its influence in the economy and culture, coupled with the awareness of its economic and demographic superiority, is indeed worrisome. For example, the newspaper Silk Road. Cultural Development has become the country's largest weekly with a circulation of about 25,000 copies, published in three languages-Russian, Kyrgyz, and Chinese-and distributed in more than 1,000 settlements across Kyrgyzstan (Siluxgc, 2017). Naturally, there is nothing wrong with publishing a newspaper, but it is frightening when a neighboring state takes a niche that should be occupied by the national government.

There are also inter-ethnic nuances associated with the persecution of Muslims, including ethnic Kyrgyz, in XUAR, and efforts to build a mono-ethnic state in Kyrgyzstan. For example, in January 2019, members of the Kyrk Choro public movement, known for its radical views, demanded a ban on marriages between Chinese citizens and Kyrgyz women, as well as the restoration of the nationality field in passports (Musabaeva, 2019), which should prevent the descendants of mixed marriages from posing as ethnic Kyrgyz (nationality is determined by the father's nationality, and if this field is restored, the children will have to be recorded as Chinese).

It is noteworthy that sociological surveys conducted by the U.S.'s International Republican Institute record the dependence of public sentiment in Kyrgyzstan with regard to China on the information background. For example, in 2017-2019, there was a sharp transition 
from a positive result of $70 \%$ "good" and 11\% "bad" (IRI, 2018) to a negative result of 39\% "good" and 31\% "bad" (IRI, 2019). A year later, the result again was acceptably positive: 55\% "good" and 20\% "bad" (IRI, 2020). Without going into the particularities of American sociological methodologies, which may be responsible for the high volatility of estimates, we can note that the most obvious explanation for such dramatic fluctuations in sentiment is its isolation from real relationships and susceptibility to influence by the media, for which the anti-Chinese agenda seems to be an effective way to increase viewing statistics and citation.

\section{MANIFESTATIONS OF SINOPHOBIA IN RUSSIA}

In the eastern regions of Russia, anti-Chinese sentiment in the last decade was much weaker than that in the Central Asian countries considered above. There are three reasons for this.

Firstly, sociological studies show that residents of the Russian Far East are much more willing to cooperate with China now than they were in the early 2000s (Blyaker, 2004, Larin, 2018, p.29). However, it is important to understand that even in the border areas the perception of China remains "very vague" despite good cooperation in the field of foreign affairs (Ivanov, 2017, p.111). Both survey data and field studies show that the image of China improved in 2014-2015, when Russia was at loggerheads with the West, and China began to be seen as the main geopolitical ally of Russia (Ibid., p.113).

Secondly, Chinese representatives (in particular, diplomats) act more cautiously and tactfully with regard to Russia than they do towards other post-Soviet states, and make fewer provocative statements and steps (Denisov, 2020).

Thirdly, the scale of Chinese capital penetration and migration to the eastern regions of Russia is far from expansion (Zuenko, 2019, p. 106). Moreover, there is a clear downward trend in the employment of Chinese workers in Russia (Ibid., p.110). Chinese investment projects are perceived-at least by officials and part of the Russian business community and the public-as a positive and desirable result of interaction with China, which contrasts with the realities of the 
1990s-2000s, when similar projects caused more concern. And yet, the pragmatic attitude towards China as a foreign trade partner and a source of investment controversially coexists with conspiratorial and alarmist views (Ivanov, 2017, p.116).

Are these concerns justified? Indeed, Chinese business activities remain largely in the "shadow": many enterprises mimic Russian ones, informal agreements prevail, and the declared amount of work does not always match the actual one. In reality, there are no reliable statistics either on the volume of investments or the number of Chinese working in the Russian Far East (Kashin, 2017). As a result, people do not trust either official data or expert statements, and still perceive most of Chinese investment initiatives as a threat rather than opportunity. This happens partly due to commercial media, which, in pursuit of high viewing ratings, tend to exaggerate the scale of the Chinese presence and use catchy headlines that focus on the negative aspects of cooperation with China.

All this creates a favorable atmosphere for manipulating public opinion and inciting Sinophobic sentiments, which triggered two antiChinese protests over the past decade, both occurring in the Baikal region. In the summer of 2015, the population of the Trans-Baikal Territory (Zabaykalsky Krai) reacted negatively to the signing by the regional administration of a letter of intent, reiterating its readiness to lease 115,000 hectares of agricultural land and the Mogoitui industrial zone to the Chinese company Huae Xingbang (a subsidiary of Zoje Resources Investment Corporation) for 49 years. Several rallies were held in Chita, bringing together no more than 150 people, although the organizers had expected up to 5,000 (Chita, 2015). State Duma deputies sent a request to the Prosecutor's Office and also called for public hearings or even a referendum on the matter. As a result, investors abandoned their plans to do business in the region, and the facilities offered to them remained vacant (Chita, 2020).

In the spring of 2019, protests began in the Irkutsk Region over the construction by Aquasib (99\% owned by a Chinese investor from Daqing, existing since 2012) of a plant for bottling Baikal water in the village of Kultuk. Since 2017, the project had been listed as a 
regional investment project. In April 2017, the first article and an electronic petition appeared in the Irkutsk media demanding that the construction be stopped, but collected just a couple of hundred signatures (Taiga, 2017). However, at the end of February 2019, information about the project began to circulate in the media again and immediately caused a stir in social networks. As a result, on March 24, "For Clean Baikal" actions were held in 30 cities, including Moscow, and number of foreign capitals, and more than a million people signed the electronic petition.

The main complaint of environmental experts was that the trenches for supplying water to the plant had been dug through the Talovsky marshes, the nesting and wintering site of Red-Book birds. However social networks and most publications placed the emphasis on the Chinese origin of the investor. In particular, they claimed that the sale of bottled water would drain Lake Baikal. So the protest, initially purely environmental, acquired the features of a xenophobic action (Telegina, 2019), and this is exactly how it was interpreted by the Chinese media (see, for example, Hengshui, 2019), which, in turn, fueled anti-Russian rhetoric in Chinese social networks (Sina, 2019).

The Prosecutor's Office of the Irkutsk Region urgently inspected the construction site and found several violations. State Duma deputies became interested in the project and visited Kultuk on March 29. In April, the court upheld a petition filed by the Baikal Environmental Prosecutor's Office to stop the construction. The court also ordered a halt to the operation of the water bottling plant in the village of Baikalsk, owned by the company Ozero Baikal-Long. Aquasib's appeal against the suspension of construction was rejected twice. The issues of compensation for investments already made and the dismantling of the unfinished building remain unresolved.

It is noteworthy that several water bottling plants (for example, Baikalsea) are already operating on Lake Baikal. This business attracted Russian tycoon Oleg Deripaska, who bought a plant in the village of Baikal in 2018. The plant can take more than 70 million liters of water per year from the lake and then sell bottled water on the promising Chinese market (Telegina, 2019). 
So both conflicts were most likely caused by economic competition, in which the Chinese origin of investments was just a convenient pretext for provoking public discontent. "Dormant" Sinophobia was easily cranked up, including through electronic media, biased or simply interested in higher viewing ratings. Politicians also found anti-Chinese rhetoric beneficial as it allowed them to gain political capital. Under public pressure, regional officials refused to support the projects, fearing to lose their posts if the situation in the region worsened.

As in the case of Central Asia, the incidents in Russia involved an external factor and internal political struggle, which helped stir up public discontent over Chinese investment projects. An analysis of media publications shows that the events were covered most actively by websites receiving foreign funding (primarily Prague-based "Siberia. Realities," which is another project of Radio Liberty). Some observers believe that the conflict was inspired by the political struggle between the Communist Party and the United Russia party, which compete for influence in the Irkutsk Region (Telegina, 2019). Interestingly, both parties actively used anti-Chinese rhetoric, realizing that it would help them win public support.

\section{CONCLUSION. FORECASTS AND RECOMMENDATIONS}

In all the situations considered above, the key problem was the lack of public trust in the government. Anti-Chinese protests took place not because Chinese companies could do some harm to the local economy, but because society did not trust the official statements of government representatives about the positive role of cooperation projects with China, saw attempts to conceal real motives, and suspected the authorities of collusive corruption, incompetence, and shortsightedness. In addition, the public discontent was fueled by the local population's concern about the ecological well-being of their region and the fear that land could be handed over to China for permanent use.

At the same time, all of the abovementioned cases exposed the failure of the existing government-society feedback mechanisms. Influencers in social networks turned out to be much more convincing 
for ordinary people than government officials, even though their statements often were at odds with common sense.

The media (especially electronic media) also played a negative role. By pursuing an independent editorial policy and focusing on commercial indicators (giving priority to the number of viewings as the key criterion for advertisers), they consciously or unknowingly provoked a public outcry by using provocative headlines and photographs, manipulating quotes, etc.

At the same time, several specific features can be distinguished.

Society in Kazakhstan and Kyrgyzstan turns out to be much more easily mobilized for protests, which can indicate both a national psychological characteristic of the two fraternal peoples-Kazakh and Kyrgyz-and relative weakness of the state. The influence of foreign NGOs, which are much more influential in these countries than in Russia, also plays a role. Sinophobic sentiment in Central Asian countries is characterized by interethnic and religious motives (solidarity with compatriots and co-believers persecuted in China, fear that immigration or mixed marriages may "contaminate the purity" of the national state).

In the eastern regions of Russia, ethnic and religious motives are not manifest, and Sinophobia is traditionally associated with a primitively understood demographic threat ("if 107 million people live in Northeast China and only eight million in the Russian Far East, then the Chinese will want to move in here") and geopolitical motives (fear that Russia will lose its eastern territories). The scale of anti-Chinese protests in Russia is incomparable with that in Central Asia: while tens of thousands of protesters can take to the streets in Kazakhstan and Kyrgyzstan, no more than a couple of hundred protesters are ready to do so in Irkutsk and Chita, and the "discontent" of the rest, as a rule, is limited to social networks.

It is noteworthy that in all of the abovementioned countries, the protesters were able to achieve their demands to a certain extent and change the initial decisions of the authorities: Kazakhstan introduced a moratorium on amendments to the Land Code, and Kyrgyzstan and Russia stopped the implementation of Chinese investment projects. 
On the one hand, the authorities have to listen more carefully to civil society, and China has to adjust its foreign policy, taking into account the interests of the local population. On the other hand, protests, inspired by business competitors and instigated by external actors, worsen the investment climate, force foreign investors to give up their plans to do business in these countries, and negatively affect the socioeconomic situation in peripheral regions.

An analysis of the causes and mechanisms of anti-Chinese protests in Kazakhstan, Kyrgyzstan, and the Baikal region of Russia shows that Sinophobic sentiments may also manifest themselves in other parts of the post-Soviet space as well. An analysis comparing them with similar manifestations in other parts of the world (U.S., Europe, Australia, Southeast Asia) appears to be a promising area to explore and undoubtedly requires a separate study.

Based on our conclusions for the post-Soviet space, in order to reduce the likelihood of such protests impeding the normal development of relations with China, we propose some recommendations on how to create a mechanism for building a dialogue between the government and society:

Firstly, it is necessary to inform the public that cooperation with China is purely pragmatic and based on the national interests of the country. Secondly, bilateral trade and Chinese investment projects in strategic sectors of the economy should be open to public discussion. It is important to ensure the transparency of joint projects. Thirdly, it is necessary to have a dialogue with people, focusing on the benefits and advantages their region will get from a project. Finally, false myths should be dispelled and a positive information background created. The example of Kazakhstan is indicative. Its authorities were late in informing the public about the projects being implemented, and as a result, a myth spread that obsolete equipment would be supplied to Kazakhstan, which provoked anti-Chinese feelings. In the case of the Baikal and Trans-Baikal projects, critics focused on environmental consequences, but there were no influential opinion leaders who could shift public attention to the economic benefits of the projects. 
Taking these recommendations into account when working with people during the implementation of large-scale joint projects with Beijing will reduce the likelihood of critical misunderstandings between the authorities and society on the development of economic cooperation with China. High awareness of the population and availability of information on bilateral cooperation projects will provide the basis for a substantiated position in disputes with possible opponents of Beijing.

\section{References}

Akchabar, 2016. Vse o vneshnih zaīmah, stavkah po kreditam, druzhbe s Kitaem i EAES: samye tochnye zayavleniya Atambaeva o finansah i ekonomike [Everything on External Loans, Credit Rates, Friendship with China and EAEU: Exact Statements by Atambaev on Finance and Economy]. Akchabar.kg, 02 December [online]. Available at: $<$ https://www.akchabar.kg/ru/ article/economy/atambaev-press/> [Accessed 5 April 2020].

Allison, G., 2017. Destined for War: Can America and China Escape Thucydides's Trap? Boston, MA: Houghton Mifflin Harcourt.

Barr, W. P., 2020. Attorney General William P. Barr Delivers the Keynote Address at the Department of Justice's China Initiative Conference. The United States Department of Justice, 6 February [online]. Available at: $<$ https://www.justice. gov/opa/speech/attorney-general-william-p-barr-delivers-keynote-addressdepartment-justices-china> [Accessed 29 April 2020].

Blyakher, L., 2004. Politicheskie mify Dal'nego Vostoka [Political Myths of the Far East]. Polis. Political Studies, No.5, pp. 28-39. DOI: 10.17976/jpps/2004.05.04 Bremmer, I., 2019. The End of the American Order: Ian Bremmer's Speech at the 2019 GZERO Summit. Eurasia Group, 18 November [online]. Available at: $<$ https://www.eurasiagroup.net/live-post/end-of-american-order-ian-bremmer2019-gzero-summit-speech> [Accessed 23 April 2020].

Brzezinski, Z., 2017. How to Address Strategic Insecurity in a Turbulent Age. Huffington Post, 3 January [online]. Available at: <https://www.huffpost.com/ entry/us-china-russia-relations_b_586955dbe4b0de3a08f8e3e0?section=us_ world $>$ [Accessed 1 May 2020].

Burdin, V., 2013. Auezov svalilsya s luny [Auezov Must Be the Man in the Moon]. Time.kz, 28 May [online]. Available at: <https://time.kz/articles/ zloba/2013/08/28/auezov-svalilsja-s-luni/> [Accessed 10 March 2020]. 
Burrows, M. and Manning R., 2015. Kissinger's Nightmare: How an Inverted US-China-Russia May Be Game-Changer. Valdai Papers, No.33, November [online]. Available at: <https://valdaiclub.com/files/11410/> [Accessed 1 May 2020].

Chita, 2015. Okolo 100 chelovek vmesto zayavlennyh 5 tys. prishli na miting protiv arendy zemli v krae [About 100 Protesters Showed Up instead of Declared 5,000 at the Rally Against Land Rent in the Region]. Chita.ru, 30 August [online]. Available at: <chita.ru/news/77321/> [Accessed 10 March 2020].

Chita, 2020. Bardaleev zayavil o poiske investora dlya prostaivayustcheī 9 let Mogoītuiskoī promzony [Bardaleev Declared Search for an Investor for Mogoitui Industrial Area]. Chita.ru, 17 February [online]. Available at: <chita. ru/news/141922> [Accessed 10 March 2020].

Conflict, 2019. Konflikt na Solton-Sary. Vlastyam dali tri chasa na vypolnenie trebovanii [Conflict on Salton-Sary. Authorities Were Given Three Hours to Meet the Demands]. 24.kg, 06 August [online]. Available at: <https://24.kg/ proisshestvija/125469_konflikt_nasolton-saryi_vlastyam_dali_tri_chasa_ navyipolnenie_trebovaniy_/> [Accessed 5 April 2020].

Degterev, D.A. and Istomin, I.A., 2015. Systemnoye modelirovanie v mezhdunarodnyh otnosheniyah [System Modelling of International Relations]. Mirovaya ekonomika i mezhdunarodnye otnoshenia, 7, pp.17-30.

Denisov, I. and Zuenko, I., 2020. Pochemu novyī yazyk kitaīskoī diplomatii zvuchit tak grubo [Why the New Language of Chinese Diplomacy Sounds Rude]. Profile.ru [online]. Available at: < https://profile.ru/abroad/pochemu-novyj-yazykkitajskoj-diplomatii-zvuchit-tak-grubo-320380/> [Accessed 10 June 2020].

Diatlov, V., 2000. Migratsiya kitaītsev i diskussiya o "zheltoī opasnosti" v dorevolyutsionnoī Rossii [Chinese Migration and Discussions about Yellow Peril in Russia before 1917]. Vestnik Evrazii, 1, pp.63-89.

Dittmer, L., 1981. The Strategic Triangle: An Elementary Game-Theoretical Analysis. World Politics, 33(4), pp. 485-515.

Dobbins, J., Schatz, H. and Wyne, A., 2018. Russia Is a Rogue, Not a Peer; China Is a Peer, Not a Rogue. Different Challenges, Different Responses. Santa Monica, CA: RAND Corporation.

Farrell, H. and Newman, A., 2020. The Twilight of America's Financial Empire. 24 January. Foreign Affairs, No. 1(24), January [online]. Available at: <https:// www.foreignaffairs.com/articles/2020-01-24/twilight-americas-financialempire> [Accessed 29 April 2020]. 
Fergana, 2016. V Kazakhstane idut nesanktsionirovannye mitingi protiv prodazhi zemli [Unauthorized Rallies against the Sale of Land Have Swept across Kazakhstan]. Fergana, 27 April [online]. Available at: <https://www. fergananews.com/news/24706f $>$ [Accessed 13 January 2020].

Ferguson, N. and Schularick, M., 2007. "Chimerica" and the Global Asset Market Boom. International Finance, 10 (3), pp. 215- 239.

Ferguson, N. and Xu, X., 2018. Making Chimerica Great Again. International Finance, 21(3), pp.239-252.

Gabuev, A. and Zuenko, I., 2018. The "Belt and Road" in Russia: Evolution of Expert Discourse. Russia in Global Affairs, 16 (4), pp.142-163. DOI: 10.31278/1810-6374-2018-16-4-142-163

Glushkova, S., 2011. Tajikistan peredal chast' zemli Kitayu [Tajikistan gave part of the land to China]. Azattyq.org, 06 October. Available at $<$ https://rus.azattyq. org/a/china_tajikistan_kazakhstan_kyrgyzstan_land/24350707.html $>$ [Accessed 5 April 2020].

Goldstein, J. and Freeman, J., 1990. Three-Way Street: Strategic Reciprocity in World Politics. Chicago: University of Chicago Press.

Hengshui, 2019. Zhongguoren zai Beijiaerhu jian shuichang you duonan? [What Difficulties Did Chinese Investors Face in Building a Water Plant on Lake Baikal?] Hengshuizixun, 23 August [online]. Available at: <hsfcp.com/ guoji/112669.html> [Accessed 10 March 2020].

Hughes, G., 2012. Gornodobyvayustchaya deyatel'nost', razvitie i okruzhayustchaya sreda v Tsentral'noī Azii: prilozhenie k instrumentariyu s prakticheskimi primerami [Mining, Development and the Environment in Central Asia: A Toolkit Supplement with Case Studies]. uef.fi Available at: $<$ https://epublications.uef.fi/pub/urn_isbn_978-952-61-0936-7/urn_isbn_978952-61-0936-7.pdf> [Accessed 5 April 2020].

Ivanov, S., 2017. Pragmatizm i konspirologiya: predstavleniya chinovnikov yuga Dal'nego Vostoka Rossii o kitaīskih investorah [Pragmatism and Conspiracy Theories: The Officials' Perception of Chinese Investors in the Russian Far East]. Izvestiya Irkutskogo Gosudarstvennogo Universiteta: Politics and Religion Studies, 21, pp.110-117.

IRI, 2018. Public Opinion Survey of Kyrgyzstan Residents in 2017. IRI.org [online]. Available at: <https://www.iri.org/sites/default/files/2018-2-5_iri_poll_ presentation_kyrgyzstan.pdf> [Accessed 4 June 2020]. 
IRI, 2019. Public Opinion Survey of Kyrgyzstan Residents in 2018. IRI.org [online]. Available at: <https://www.iri.org/sites/default/files/february_2019_ kyrgyzstan_poll.pdf> [Accessed 4 June 2020].

IRI, 2020. Public Opinion Survey Residents of Kyrgyzstan in year 2019, 2020. IRI.org [online]. Available at: <https://www.iri.org/sites/default/files/final_ kygyzstan_slides.pdf> [Accessed 4 June 2020].

Jervis, R., 1997. System Effects: Complexity in Political and Social Life. Princeton: Princeton University Press.

Jumasheva, A., 2020. V At-Bashi zakryli proekt po stroitel'stvu logisticheskogo tsentra [The Project for Building a Logistic Center in At-bashi Has Been Closed]. 24. kg, 17 February [online]. Available at: $<$ https://24.kg/obschestvo/143895_vatbashi_zakryili_proekt_postroitelstvu_logisticheskogo_tsentra/> [Accessed 5 April 2020].

Kashin, V., 2017. Mnogo li Kitaī investiruet v Rossiyu? [How Much Does China Invest in Russia?] Valdai Club, 09 June [online]. Available at: $<$ ru.valdaiclub.com/a/ highlights/mnogo-li-kitay-investiruet-v-rossiyu> [Accessed 10 March 2020].

Kashin, V., 2019. Tacit Alliance: Russia and China Take Military Partnership to a New Level. Carnegie Moscow Center, 22 October [online]. Available at: $<$ https:// carnegie.ru/commentary/80136> [Accessed 29 April 2020].

Khabar, 2019. Dokumental'nyī fil'm "Blizkiī sosed. "Real'nost' bez mifov" [Documentary "Close Neighbor. Reality without Myths"]. Khabar TV-channel, 21 October [online]. Available at: $<$ https://khabar.kz/ru/arkhiv/dokumentalnyefilmy/item/116543-dokumentalnyj-film-blizkij-sosed-realnost-bez-mifov> [Accessed 23 January 2020].

Kissinger, H., 1979. The White House Years. Boston, Mass.: Little, Brown and Company.

Klevtsova, A., 2019. Antikitaīskie protesty i ugroza masshtabnogo politicheskogo krizisa [Anti-China Protests and the Threat of a Broad-Scale Political Crisis]. RadioAzattyk, 14 September [online]. Available at: <https://rus.azattyq. org/a/press-review-kazakhstan-tokayev-anti-china-protests/30163788.html> [Accessed 20 September 2019].

Kloop, 2019. Strah i nenavist' na Solton-Sary: istorya o tom pochemu my nuzhny Kitayu, a on nuzhen nam [Fear and Hatred in Solton-Sary. The Story of Why China Needs Us, and We Need China]. Kloop.kg, 06 November [online]. Available at: $<$ https://kloop.kg/blog/2019/11/06/strah-i-nenavist-na-solton-sary-istoriya-otom-pochemu-my-nuzhny-kitayu-a-on-nuzhen-nam/> [Accessed 5 April 2020]. 
Kovaleva, T., 2019. Kitaitsy ne budut stroit' 55 zavodov v Kazakhstane [China Will Not Build 55 Factories in Kazakhstan]. Zakon.kz, 02 September [online]. Available at: <https://www.zakon.kz/4983968-kitaytsy-ne-budut-stroit-55zavodov-v.html $>$ [Accessed 23 January 2020].

Kulintsev, Y., 2019. Aktual'ny li antikitaīskie protesty v Kazakhstane dlya rossiīskih interesov? [Are the Anti-China Protests Relevant for Russias Interests?]. Russian International Affairs Council, 04 October. Available at: <https://russiancouncil. $\mathrm{ru} /$ analytics-and-comments/analytics/aktualny-li-antikitayskie-protesty-vkazakhstane-dlya-rossiyskikh-interesov/> [Accessed 23 January 2020].

Larin, V., and Larina, L., 2018. Kitaī v obchshestvennom mnenii zhiteleì Tihookeanskoī Rossii (po itogam oprosa 2017 g.) [The Perception of China People in Pacific Russia (Results of the 2017 poll)]. Rossija i ATR, 2, pp.5-33.

Mashaev, A., 2019. Sinofobia starogo razliva [Old-Style Sinophobia]. Expert Kazakhstan. 22 October [online]. Available at: <https://expertonline.kz/ a16145/> [Accessed 01 June 2020].

Mearsheimer, J. and Walt, S., 2016. Case for Offshore Balancing. The Superior US Grand Strategy. Foreign Affairs, 95 (4), pp.70-83.

Mikhailov, G., 2016. Eto ochen' grubo, eto unizheniye. Kitaī i Sredniaya Aziya [The Regulations Are Too Tough, Humiliating. China and Central Asia]. Regnum, 11 April [online]. Available at: <https://regnum.ru/news/polit/2115193. $\mathrm{html} />$ [Accessed 01 June 2020].

Munich Security Report, 2020. Westlessness. [online]. Available at: <https:// securityconference.org/assets/user_upload/MunichSecurityReport2020.pdf> [Accessed 29 April 2020].

Musabayeva, A., 2019. Antikitaīskaya tema v Kyrgyzstane priobrela novyī impul's [The Anti-Chinese Theme Has Acquired a New Impulse in Kyrgyzstan]. Central Asian Analytical Network, 21 January [online]. Available at: <https:// caa-network.org/archives/15113> [Accessed 23 January 2020].

National Security Strategy, 2010. National Security Strategy of the United States of America. The White House, May [online]. Available at: <https:// obamawhitehouse.archives.gov/sites/default/files/rss_viewer/national_security_ strategy.pdf $>$ [Accessed 27 April 2020].

National Security Strategy, 2017. National Security Strategy of the United States of America. The White House, December [online]. Available at: <https://www. whitehouse.gov/wp-content/uploads/2017/12/NSS-Final-12-18-2017-0905.pdf> [Accessed 27 April 2020]. 
Navarro, P. and Autry, G., 2011. Death by China. Confronting the Dragon - A Global Call to Action. Upper Saddle River, NY: Person Prentice Hall.

News-Front, 2019. Zapadnye SMI tehnichno nagnetayut antikitaīskuyu ksenofobiyu v Kazahstane [Western Mass Media Consistently Promote AntiChinese Xenophobia in Kazakhstan]. News-Front, 20 September [online]. Available at: <https://news-front.info/2019/09/20/zapadnye-smi-tehnichnonagnetayut-antikitajskuyu-ksenofobiyu-v-kazahstane $>$ [Accessed 20 October 2019].

Nurmatov, E., 2019. Chem mozhet auknutsa Kyrgyzstanu sluchivsheesya v Solton-Sary? [What Does the Solton-Sary Incident Bode for Kyrgyzstan?] Azattyk.org, 08 August [online]. Available at: <https://rus.azattyk.org/a/ kyrgyzstan_solton_sary_conflict/30098810.html> [Accessed 5 April 2020].

Nye, J., 2004. Soft Power: The Means to Success in World Politics. New York, Public Affairs.

President Xi's Speech, 2015. President Xi's Speech on China-US Ties. China Daily, 24 September [online]. Available at: <https://www.chinadaily.com.cn/ world/2015xivisitus/2015-09/24/content_21964069.htm> [Accessed 20 April 2020].

RIA Novosti, 2019. V Kazakhstane zaderzhali okolo 100 chelovek na nesanktsionirovannyh mitingah [100 People Were Arrested in Kazakhstan during Non-Sanctioned Rallies]. RIA Novosti, 23 September [online]. Available at: <https://ria.ru/20190923/1558993809.html> [Accessed 13 January 2020].

Ryskulova, N., 2019. V dolgu u bol'shogo soseda. Pochemu v Kyrgyzstane boyatsa kitaīskoi ekspansii [In Debt to a Big Neighbor. Why People in Kyrgyzstan Are Apprehensive of "Chinese expansion"]. BBC.com, 07 December [online]. Available at: <https://www.bbc.com/russian/features-50678871> [Accessed 5 April 2020].

Sevostyanova, I., 2019. “Eto vran'yo!” — vitse-premier Kasymbek o perenose kitaīskih predpriyatiī v Kazakhstan [“This Is a Lie!” Says Vice Prime Minister Kasymbek about the Transfer of Chinese Factories to Kazakhstan]. Forbes Kazakhstan, 05 September [online]. Available at: <https://forbes.kz/process/ economy/eto_vrane_-_vitse-premer_jenis_kasyimbek_o_perenose_kitayskih_ predpriyatiy_v_kazahstan> [Accessed 20 October 2019].

Siluxgc, 2017. Gazeta "Shelkovyī put'. Kul'turnoe razvitie” lidiruyet sredi kyrgyzskih SMI [“Shelkovy put'. Kulturnoe razvitie” Newspaper Leads among Kyrgyz Media]. Siluxgc.com, 15 November [online]. Available at: <http:// ru.siluxgc.com/html/R1413/201711/21069986846746.shtml $>$ [Accessed 5 April 2020]. 
Sina, 2019. Beijiaerhu de shui bu neng mai gei Zhongguo? Eluosiren ziji xian chaoqilaile [Not Possible to Sell the Baikal Water to China? Russians Disagree]. Sina.com, 23 March [online]. Available at: $<$ k.sina.com.cn/article_3057540037_ b63e5bc502000fvb3.html> [Accessed 10 March 2020].

Sputnik, 2019. Skol'ko deneg dolzhen Kyrgyzstan Kitayu, grafik po godam [How Much Kyrgyzstan Owes to China. Yearly Chart. Sputnik.kg, 06 August [online]. Available at: <https://ru.sputnik.kg/economy/20190806/1045308431/ kyrgyzstan-china-gosdolg-rost-grafik.html $>$ [Accessed 5 April 2020].

Taiga, 2017. Ne speshite stavit' podpis' [Don't Rush to Sign]. Taiga.info, 03 May [online]. Available at: <tayga.info/134039> [Accessed 10 March 2020].

Telegina, N., 2019. Ksenofobiya pod vidom ekologii [Xenophobia in camouflage of ecology]. Meduza, 08 May [online]. Available at: <meduza.io/ feature/2019/05/08/zavod-prevratilsya-v-shaybu> [Accessed 10 March 2020].

Umarov, T., 2019. What's Behind Protests Against China in Kazakhstan? Carnegie Moscow Center, 30 October [online]. Available at: <https://forbes.kz/ process/economy/eto_vrane_-_vitse-premer_jenis_kasyimbek_o_perenose_ kitayskih_predpriyatiy_v_kazahstan> [Accessed 23 March 2020].

Usenbaeva, T., 2020. Logistcheskyī centr v At-bashi: chto izvestno i pochemu mestnye zhiteli protiv. [At-Bashi Logistic Center: What Is Known about it and Why Local People Are Against It]. Sputnik.kg, 31 January [online]. Available at: $<$ https://ru.sputnik.kg/economy/20200131/1046935286/industrialno-torgovyjlogisticheskij-centr-at-bashi.html> [Accessed 5 April 2020].

Valdai, 2019. Valdai Discussion Club Session. 3 October [online]. Available at: $<$ http://en.kremlin.ru/events/president/news/61719/videos> [Accessed 21 April 2020].

Zhang, Chunjie, 2008. From Sinophilia to Sinophobia: China, History, and Recognition. Colloquia Germanica, 41 (2), pp. 97-110.

Zuenko, I., 2018. Peregiby Shelkovogo puti: kak Kitaī reshaet uīgurskyī vopros [Problems on the Silk Road: How China Resolves the Uyghur Issue]. Carnegie Moscow Center. 18 April [online]. Available at: <https://carnegie.ru/ commentary/76013> [Accessed 23 March 2020].

Zuenko, I., Ivanov, S. and Savchenko, A., 2019. Kitaīskie investitsii na rossī̄skom Dal'nem Vostoke [Chinese investments on the Russian Far East]. Mirovaya ekonomika i mezhdunarodnye otnosheniya, 11, pp. 105-113. 